\title{
The Decline of Political Party Public Financing and the Emergence of Political Cartel in Indonesia: A Study of Partai Kebangkitan Bangsa
}

\author{
Rofiq \\ \{rofiq@walisongo.ac.id\} \\ Walisongo State Islamic University, Semarang, Indonesia
}

\begin{abstract}
This article investigates the importance of public financing for political parties to meet the general election criteria and how do political cartels emerge in Indonesia. The ease of raising public funds enable political parties to conduct socialization and promotion to their constituents intensely, which means that the large amount of public funds will increase the intensity of campaigns that can provide political parties with opportunities to win competition for running public office and other positions. However, along with the increasing of competition among political parties in Indonesia, for the Partai Kebangkitan Bangsa (PKB) public fundraising is not necessarily easy to obtain, even after the 1999 General Election, public fundraising of PKB has collapsed which resulted in the strengthening of political cartel in the Party. This study will explain how the collapse of public fundraising and the factors that led to political cartelization in PKB. This research found that one of the basic reasons for the collapse of PKB public fundraising and strengthening of political cartel in the party is due to the occurrence of political distrust by constituents towards the party. Besides, the electoral system and party system in Indonesia add to a series of factors that encourage PKB to seek alternative sources of financing to meet its operational needs. The alternative sources of financing are obtained from internal and external sources. The internal sources of party financing rely on contributions from political elites and political dowries from candidates who run for regional elections, while external sources of party financing come from donations from private sectors.
\end{abstract}

Keywords: PKB; Public Financing; Alternative Financing; Cartel Party

\section{Introduction}

One of the most fundamental aspects of politics is resources/financing. In a system of electoral democracy, various countries have different policies in term of internal and external funding for parties in order to maintain the sustainability of party financing. It depends on the economic foundation of the country itself. Public financing as an alternative option in various countries is commonly in the form of 'co-funding', followed by the imposition of certain 
limitations either through the membership dues channel or through other channels such as donations from private parties.

In fact, in many countries political party financing still depends on the government fund in accordance with following regulations. Parties usually receive funds from the government based on the number of electoral votes they received in the election. Le Duc et al. (1996) who conducted study in 27 democratic countries found 17 cases of political parties that are highly dependent on state subsidies in accordance with the distribution of electoral votes or seats obtained after the election process.

Questions raised in this in this article consist of the followings: 1) why do many countries in the world still rely political party financing on the state budget? Is public financing cannot play important role for party operation and campaign? Are there any factors from internal political parties that hinder public financing to function? Is there any difficulty in raising public funds due to the declining public trust toward the party itself? And how has the public financing brought about cartels politics in Indonesia? This article is based on the results of qualitative research, using rational choice method and approach. This article will examine further how the public financing dynamics has been taking place and is undergone by political parties in Indonesia. The focus of the study the National Awakening Party (PKB), one of the biggest islamic party.

\section{Results and Discussion}

\subsection{Decline in Public Finance}

Historically, the concept of public financing was introduced in the 1950s, initially in several Latin American countries, then followed by countries on the European continent. Financing instruments is used during political competition and campaigns using the public money and subsequently become the standard of democratic process in many countries. Public funding is often combined with private sources. In their study, Ortín and Schultz, (2000:781) have found that in various countries there is no transparent report by political parties on the results of obtaining funds from public and private sources. As in Croatia, all kinds of party reports until the end of the 1990s, although political parties obtained financial budgets as stipulated in the Political Parties Act 1993, the fact is that political parties do not report their income and expenses to public transparently as required by the law.

So far, the financing of political parties is dependent on government budget/resources. The proper theory of public financing instrument for political parties can only be applied for states with established democratic process, such as those in Western Europe, Canada, and the US. However, in the long turn, it is possibly carried out by countries around the world, including Indonesia. The public funding of political parties is of new concept in Europe and became increasingly important in the European post-war period. Historically, political parties in Western European liberal democracies have relied heavily on private contributions to finance their own activities. There are several classifications of public funding for parties.

Cadre parties generally rely on contributions from the-haves or donations from private businesses, while mass parties usually rely more on income streams from structural administrator such as contributions from party administrators or party members to expand the base of financial support (Biezen, 2008: 345). Biezen (2008) also emphasized that in almost all European democratic countries, the financial sources of political parties have been directly subsidized by the state. The introduction of public finance for political parties that do not 
receive subsidies from the state has encouraged the emergence of cartel parties that depend on state financial resources for themselves to exist. Therefore, parties in Western Europe have traditionally relied on public funding contributions. The following is an illustration of the financing of political parties in various countries which are subsidized by the state:

Table 1 . The \% of party financing from both state and private

\begin{tabular}{lcccc}
\hline No & Negara & (\%) Bantuan Keuangan Partai & (\%) Sumber dan Lainya & IPK (Rank) \\
\hline 1. & Belegia & 85 & 15 & $75(17)$ \\
2. & Denmark & 75 & 25 & $88(1)$ \\
3. & Finlandia & 75 & 25 & $85(3)$ \\
4. & Hungaria & 60 & 40 & $46(64)$ \\
5. & Italia & 82 & 18 & $52(53)$ \\
6. & Belanda & 35 & 65 & $82(8)$ \\
7. & Norwergia & 67,4 & 32,6 & $84(7)$ \\
8. & Polandia & 54 & 46 & $60(36)$ \\
9. & Portugal & 80 & 20 & $64(30)$ \\
10. & Spanyol & 87,5 & 12,5 & $58(41)$ \\
11. & Turki & 90 & 10 & $41(78)$ \\
12. & Inggris & 35 & 65 & $80(11)$ \\
13. & Jerman & 30 & 70 & $80(11)$ \\
14. & Meksiko & 70 & 30 & $28(138)$ \\
15. & Jepang & 23 & 77 & $73(18)$ \\
16. & Australia & 30 & 70 & $77(13)$ \\
17. & Amerika & 30 & 70 & $77(22)$ \\
18. & Korea Selatan & 40 & 60 & $57(45)$ \\
19. & Malaysia & 0 & 100 & $47(61)$ \\
20. & Thailand & Dengan Bobot & - & $37(99)$ \\
\hline \multicolumn{5}{r}{ Source: GRECO (n.d.). "Third Evaluation Round: Evaluation and Compliance Reports". }
\end{tabular}

Illegal practices in political financing such as corruption, collusion, and nepotism is a result of the party needs for operation which require high costs (Mas'oed and Sayirani, 2011: 69). In his study of the financing of political parties in Indonesia, Mietzner (2007) describes various cases related to the withholding of political aid funds (Banpol). After a series of cuts to Banpol funds, political parties were forced to look for alternative sources of financing to cover their increased costs, especially during general elections. Often, these new sources of income are carried out through illegal means and activities.

In indoenesia, Since 2004 General Electio, the emergence of illegal financing appeared on the surface and has been exacerbated by the decision of the Constitutional Court (MK) No. 2224/PUU-VI/2008 concerning the electoral system in 2009. The decision has urge the system to change from a closed proportional system to an open list proportional system. This has impacted on the illegal practice of political financing that subsequently led to the cartelization of political party financing as the election costs are expensive. As an instance, according to Sumarmo, one of the candidates for the 2015 Semarang City Mayor Election proposed by PKB; despite he did not mention how much money was spent in his candidacy, he contended that his comptetior Sigit-Agus spent more money.

"My guess is that Pak Sigit run out of around 40 billion, because he was very ambitious to win the fight so he spent a lot of money. Pak Sigit is indeed very strong from a financial point of view due to his business background. Unlike me, who is not a businessman, I am a civil servant. My career started from the position of head of the 
sub-district, sub-district head, then continued to be the regional secretary (Sekda) and then became the mayor of Semarang (interview, 17/03/21).

Sumarmo's explanation was echoed by Hasyim As'ari, a member of the Indonesian KPU. In his critical note, according to As'ari, many candidates reported that their personal wealth was far less than the total amount of campaign financing they spent. This data was obtained by As'ari from campaign finance reports to the General Election Commission of the Republic of Indonesia. This confirms that a lot of the funds that flowed illegally during the campaign period were carried out by the candidates. He believed that the difference in the reported campaign funds did not come from public funds but came from private parties. (interview, 15/06/2021).

In this study, the researcher has not found the practice of raising public funds, especially from the grassroots, carried out by parties in Indonesia. There are some parties that are trying to raise funds from the public but have not been maximized. The unsuccessful public fundraising is caused by public trust in the party which is still very low. Grace Natalie, Chairperson of the Indonesian Solidarity Party (PSI), is trying to raise funds from the public for her party's funding. In a fundraising event held by her party in Jakarta, Natalie admitted that she received a total of $\mathrm{Rp} 39$ million. According to her, those who contributed $\mathrm{Rp}$. 200,000 or Rp. 5 million, is still accepted. The party continues to carry out fundraising actions as a source of party financing which will be managed transparently and accountably (Kompas.com: 14/09/2017).

Prabowo Subianto, the General Chairperson of the Geridera Party, has also raised public funds. Prabowo said that public fundraising was carried out to support his political struggle in running as a 2019 presidential candidate and to support the Gerindra Party in the Pilkada. Prabowo said the current economic system made political costs high. This makes a lot of potential leaders looking for funders. He called this program the Galang Perjuangan program. "I designed a program to raise funds from the people directly from my supporters and Gerindra supporters." Prabowo said (merdeka.com, Monday, June 25, 2018). The public can donate directly through the account number 849500200100002 Bank BNI/BNI Syariah in the name of Galang Perjuangan Prabowo Subianto. However, what Prabowo Subianto did was not optimal and was not followed by other administrators at the regional level. As a result, fundraising through the public gets only a small amount of money. According to the Treasurer of the Gerinda Party, Thomas Djiwandono, total public funds that have been collected as of 13:25, Thursday (11/29/2018), reached $\mathrm{Rp} 2,382,352,113$ (Rp2.38 billion). The funds increased by around Rp. 300 million from the previous two days (tirto.id, 29/11/2018)

Other than PSI and Gerindra, no parties in Indonesia have tried public fundraising. PKB, for instance, does not have a financing scheme from the public. So far, PKB rely on Banpol funds and dues from elected legislative members as well as other funds both from internal parties and external parties. PKB experienced various obstacles in its efforts to raise public funds, the obstacles faced by PKB due to the weak public trust in political parties in Indonesia. In addition to the public image which assumes that political parties are political institutions that have sufficient funding, so that there is no need for donations from the public, on the other hand, the public indeed hopes that political parties will assist them in the form of financial or other assistance.

In various public opinion polls conducted by various research institutions such as the Indonesian Survey Institute (LSI), Saiful Mujani Research and Consulting (SMRC) since 2004, Asia Barometer and Charta Politica have consistently found the fact that people have negative views and tend to distrust both the political party and the politicians. This is due to the fact that politicians who fill government positions consistently raise negative perceptions. 
Many political party cadres who have sat in the parliemant or have executive position within the government have been involved in various corruption cases. This problem causes the public trust (Rakhman and Muhammad, 2019: 158-159)

As the largest Islamic party in Indonesia, PKB requires sufficient funds for its party operations. However, raising public funds is a challenge for PKB as a political organization founded by the NU mass organization. In the NU tradition, fundraising and the public are important schemes in financing this largest Islamic organization. Public fundraising is not only carried out by NU as the parent organization but its under bow institutions such as Lazisnu or other its other autonomous bodies such as Muslimat, Fatayat and GP Ansor also raise public funds. The public fundraising involves nahdliyin people which they call the 'NU Coin'. NU Coins are a form of public fundraising managed by Lazisnu to be distributed to NU constituents and used for the institutional need like for natural disasters/disasters, scholarships, building mosques, establishing educational institutions, establishing health institutions etc.

Muhamad Mahsun (Chairman of the Semarang City PKB DPC Period (2021-2026) admitted "his party has never raised public funds, his party mostly raises funds from the contributions of party members who sit in the DPR, Banpol funds and funds from philanthropists who are not binding, Mahsun did not say who the benefactors had donated to their party, what was clear was that there were donations from philanthropists, the total contribution of each member of the legislature was 7.5 million with the total PKB acquisition in the city of Semarang 4 seats so that if the total was 30 million rupiah per month, In addition, Semarang City PKB also receives around 200 million Banpol funds per year (interview, $31 / 3 / 21$ ). This is also reinforced by Muhamad Makmun, the Chairperson of the Kendal Regency DPRD 2019-2024 as well as (Chairman of the Kendal Regency PKB DPC for the 2021-2026 period.) in Kendal PKB has never raised public funds, he emphasized that his party relies more on Banpol funds from the government and its membership fees are high. Public fundraising has never been done because there has been no technical guidance from the DPP PKB, besides that the Kendal Regency PKB is the party that won the 2019 election so it feels unethical for the winning party to beg for funds from the community, the funds that were obtained were more than sufficient (interview, 3/4/2021).

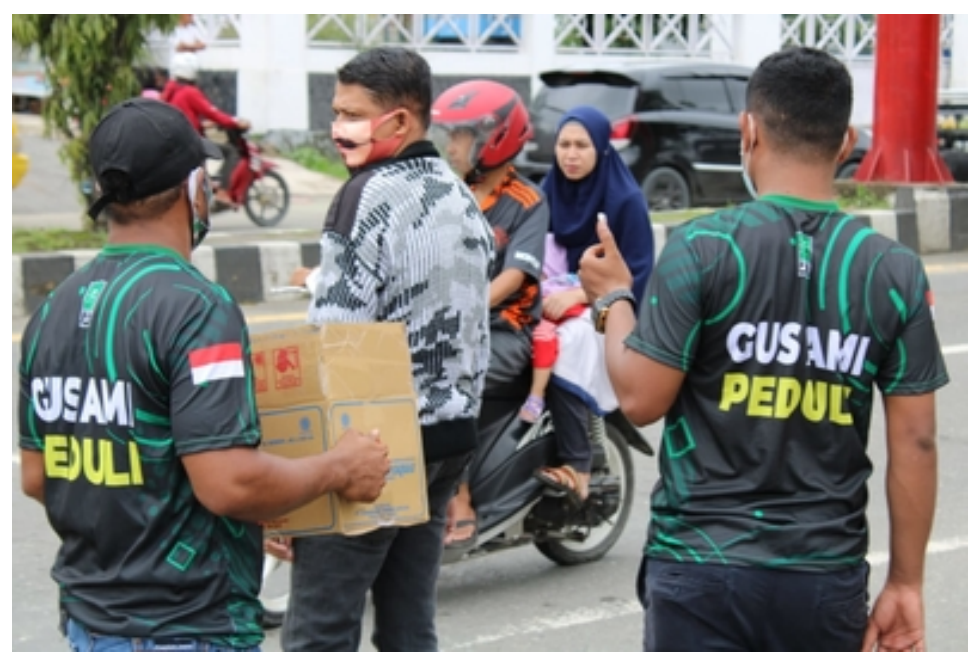

Fig. 1. fundraising in Sorong 
The researcher tried to get information more deeply on why it was difficult for PKB to raise public funds at both the central and regional levels interviewing by vice chairman of PKB, Hanif Dzakiri and one of the PKB Chairman Yaqut Cholil Qoumas. Yaqut is one of high rank person in central PKB and is now the Minister of religious affairs in the Jokowi Cabinet for the 2nd period. Yaqut says:

"Fundraising at the grassroots is not possible for any party, including PKB. Why, because there is public distrust of political parties in Indonesia, you know for yourself that the level of public trust in political parties is very low, how can political parties want to ask for funds from the public, yes it is impossible, ideally the financing of political parties is financed by the public, but which one of the public that is willing to do this financing? Only certain people who has the same political interests." (Interview, 09-06-21)

\subsection{The domination of Cartel Politics}

The term cartel in politics was originally defined by Kirchheimer (1961): a party-state cartel, in which colluding parties to become agents of the state and use state resources to ensure their own collective survival. To ensure the continuity of this collective organization, parties allocate substantial state support to themselves and regulate party activities through the state. In their study by Katz and Mair (1995) the Cartel Party is a party that is composed of various parties who are trying to maintain their position of power. The party cartel is a combination of the formation of a party-state cartel, in which the parties break away from their social foundations and merge with the state, reducing political work and placing more emphasis on professionally managed power using 'state management' by professional politicians.

In the context of Indonesia, cartel politics begins with any competition among parties. Competition among parties that based on any particular party ideology and political party agendas has occurred at least since the 1955 elections. Although competition among parties was halted due to the authoritarianism of the New Order, a similar competition also occurred again in the 1999 election arena until the 2019 election. Competition among parties in this case became an important milestone in democratic process because its ability to create a mechanism of horizontal checks and balances. The question arising in such context is whether or not the mechanism for mutual monitoring and balancing of political power actually occurs in the practice of democracy in Indonesia.

Kuskridho Ambardi (2009) his study explains that the practice of cartel politics is caused by the party system and by the interactions among political parties occurring in various arenas of political competition. The arena of competition in this case is not only limited to the context of elections; but also on the facts of the interaction among parties occurring in the executive and legislative arenas (post-election competition). Ambardi also explains that the survival of the party is not merely about government money that is specifically allocated to them, but also the source of the party's financing obtained from any government projects.

This article examines more specifically on how the increased domination of the cartel politics in PKB. As a party that was born after the New Order, since 199, PKB has always been in the side of the ruler of the all four president eras, namely the era of Abdur Rahman Wahid (Gus Dur), Megwati, Susilo Bambang Yudhoyono (SBY), and Joko Widodo (Jokowi). The position in the ruling coalition gives PKB possible space to explore sources of financing from government projects. As Ambardi (2009) studies, cartelization can be seen as the opposite of competition and can be defined as a situation where political parties give up their 
ideological and pragmatic differences in favor of something else. this situation is possible because all parties maintain their collective survival. At the same time, PKB as a party founded by the Islamic Ormas Nahdlatul Ulama does not seem to carry the ideological mission of Ahlussunnah Wal Jama'ah in the NU tradition but is trapped in the politics of rentseeking cartels to grow the party.

There are several loopholes that can be exploited by the PKB elite. First, the economic income targeted by the elites is characterized by the high level of government involvement in the economy related to the amount of public money in any government posts. And the amount of public money that goes in and out is very large compared to the needs of the party. The fact that the government owns 107 companies which previously had 142 companies (before 2020) can provide little clue as to the size of this public money. These state-owned companies are certainly under the authority of certain ministries that can coordinate with PKB officials or elites. Thus, government posts become very attractive for parties to carry out rent hunting. In short, these government posts provide incentives where political parties can earn money.

Second, the fact that the existing law has many loopholes and the fact that the application of the law is quite weak makes it easier for parties to pursue rent-seeking. The authority of legal institutions is not able to penetrate the financial sources of political parties comprehensively. Law enforcement institutions such as the BPK, Bawaslu and KPU are only able to audit party finances from financial sources that are certainly based on the law, while illegal financing coming from government projects and other private companies are not under the authority of the institution. As a result, political parties are so free to pursue rent-seeking.

Third, the government is not inclusive to open programs that will not cause substantive debate. The aforementioned illustration explain that cartel politics in Indonesia have become increasingly massive. In this case, Ambardi gives five characteristics of cartels in the party system in Indonesia; (1) the loss of the role of party ideology as a determining factor in the behavior of party coalitions; (2) permissiveness in forming coalitions; (3) absence of opposition; (4) election results have almost no influence in determining the behavior of political parties; and (5) the strong tendency of parties to act collectively as a group. (Ambardi: 2009)

The following is an excerpt of an interview with Marwan Ja'far (Chairman of the PKB for the 2019-2024 period) who emphasizes that the practice of cartel politics is not just a figment but a political reality that is carried out by all parties in Indonesia, including PKB as the largest Islamic party with the mass base of the pesantren group, Ja'far said:

"Political parties need big funds, so political parties will place their cadres who have talent to find sources of funding from various lines. It is possible to go to certain ministry agencies or sources from the private sector using various methods, but it is impossible for parties to choose just any person/cadre to find sources of party funding. So not all cadres are burdened by the party. (Interview, 10-06-2021) 


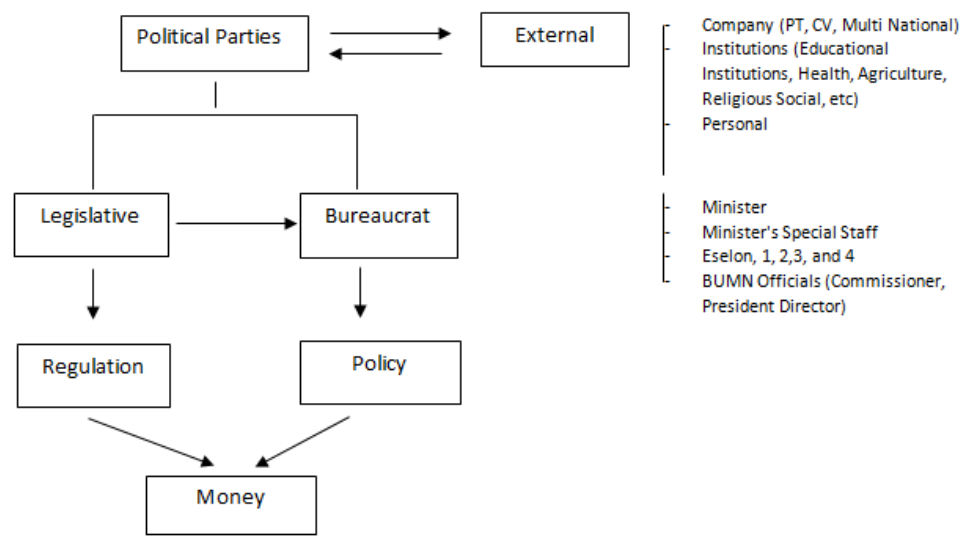

\section{Conclusion}

Fig. 2. Cartelization of Political Party Financing in Indonesia

This study has provided an illustration about how the collapse of public financing in political parties which then gave birth to increasing domination of the cartel politic practices in Indonesia. Just to conclude; in several democratic countries the dependence of political parties on state originated financing has lowered the public financing index that originates directly from grassroots. This is the case as well in in Indonesia. Parties have not been able to raise public funds as an alternative financing in the form of matching funds for finance campaign activities and other party operational costs. The dominant factor why PKB has difficulty in raising public funds from the grassroots, especially nahdliyin constituents, is that public trust in political parties in Indonesia is very weak.

When public fundraising is challenging and difficult for political parties to carry out while at the same time the practice of cartel politics is increasingly dominant, the political behavior of cartel parties has ignored ideology and programs, but is trapped in competition and interaction among parties that gives birth to a power coalition with denying the existence of opposition parties. The absence of checks and balances on government policies has trapped political parties in Indonesia in a cartel political behavior, where parties freely seek rent on government projects as sources of illegal party financing.

\section{References}

[1] Ambardi, K. (2009). Mengungkap Politik Kartel: Studi Tentang Sistem Kepartaian di Indonesia Era Reformasi (Pertama). Jakarta: Kepustakaan Populer Gramedia.

[2] Biezen, Ingrid Van, State Intervention in Party Politics: The Public Funding and Regulation of Political Parties, European Review, Academia Europæa, Vol. 16, No. 3, 337-353 r 2008

[3] Kart, Richard S and William Crotty, Handbook of party politics, : London, SAGE Publications : 2006

[4] Katz, Richard S. and Peter Mair, Changing Models of Party Organization and Party Democracy: The Emergence of the Cartel Party, London· Thousand Oaks. New Delhi, Vol. 1. No.1 pp.5-28: 1995 
[5] Katz, Richard S. The Problem of Candidate Selection and Models of Party Democracy, Party Politics Vol 7. No.3 pp.277-296, SAGE Publications London. Thousand Oaks. New Delhi Copyright (C) 2001

[6] Kirchheimer, Otto, Political Justice : The Use of Legal Procedure for Political Ends, Princeton University Press, 1961

[7] Le Duc, L., R.G. Niemi and P. Norris (Editors),. Comparing Democracies. Elections and Voting in Global Perspective. Thousand Oaks: Sage Publications. (1996)

[8] Mas'oed, Mohtar and Amalinda Savirani, Financing Politics in Indonesia, PCD Journal Vol. III No. 1-2 2011

[9] Mietzner, Marcus Funding pilkada: Illegal campaign financing in Indonesia's local elections Chapter Author(s):

[10] Rakhman, Moh.Arief Hatta Abdi Muhammad, Analisis Pengelolaan Dana Partai Terhadap Masa Depan PartaiPolitik: Sebuah Kajian Penguatan "PARTY-ID" Terhadap PartaiPolitik Baru 2019 Journal of Politics and Policy Volume 1, Number 2, Juni 2019

[11] Sartori, Giovanni, Parties and Party System: A Framework for Analysis, Volume 1, Cambridge UP, USA, 1976. 